d'épaisseur monoatomique) peut êtres révélée, dans certains cas, par la technique de l'empilement sandwich. Cette technique consiste à évaporer une nouvelle couche mince de même nature que le substrat de l'échantillon contaminé, et à étudier les courbes de par l'étude de la diffusion rasante des rayons X. (Croce, Névot \& Pardo, 1972a). Par ailleurs, si nous prenons un modèle de couche superficielle d'oxyde compact délimitée par deux interfaces rugueux identiques (ce qui revient à admettre que cette couche reproduit fidèlement les ondulations du substrat) on s'aperçoit qu'il est nécessaire de prendre des valeurs de $z_{c c}$ assez élevées: $80 \AA$ environ (voir Fig. 7) mais la simulation ainsi obtenue n'est guère meilleure, dans l'ensemble, à celle relative à un seul interface. Cet interface est donc sans doute à la fois rugueux et inhomogène et il semble que nous devions faire appel à d'autres techniques d'analyse des surfaces (par exemple, analyse ionique) pour élaborer un modèle d'interface plus précis. Signalons cependant que la présence d'une couche superficielle particulièrement mince (même réflexion spéculaire ou diffuse de rayons $X$. Une telle méthode permet également le contrôle de l'épitaxie de dépôts dont l'épaisseur est de l'ordre d'une ou plusieurs couches monoatomiques et fournit des indications précieuses quant à la diffusion de matière inter-couches qui se manifeste ultérieurement dans certains cas. (P. Croce \& L. Névot, à paraître.)

\section{Références}

Beckmann, P. \& Spizzichino, A. (1963). The Scattering of Electromagnetic Waves from Rough Surfaces, chap. 5. New York: Macmillan.

Croce, P., Devant, G., Séré, M. G. \& Verhaege, M. F. (1970). Surf. Sci. 22, 173-186.

Croce, P., Névot, L. \& Pardo, B. (1972a). C. R. Acad. Sci. Paris, 274, 803-806, 855-858.

Croce, P., Nevot, L. \& Pardo, B. (1972b). Nouv. Rev. Opt. Appl. 3, 37-50.

Parratt, L. G. (1954). Phy's. Rev. 93, 359-369.

Petzold, W. (1963). Z. angen'. Phys. 15, 525-532.

Renner, O. (1972). Czech J. Phys. B22, 1007-1016.

J. Appl. Cryst. (1974). 7, 130

\title{
One Second of Arc Optical-Resolver Controls Computerized X-ray Small-Angle Goniometer
}

\author{
BY H. LEOPOLD \\ Institut für Physikalische Chemie der Universität Graz, Heinrichstrasse 28, Graz, Austria \\ AND B. T. JENSEN \\ Kemisk Institut, Aarhus Universitet, Langelandsgade 140, 8000 Aarhus C, Denmark
}

\begin{abstract}
A new method of controlling the angular position of an X-ray small-angle goniometer was developed. A modified Kratky camera was adapted to be placed within a digital positioning loop consisting of a 20 bit optical resolver as positional reference element and a special small computer acting as an integral controller. The actual position of the goniometer arm is measured every millisecond by means of the optical resolver with an accuracy of approximately 1 second of $\operatorname{arc}\left(2 \pi / 2^{20}\right.$ radians) and compared to the nominal position stored in the computer. A deviation is converted into a suitable correcting command executed by the goniometer drive, thus keeping the actual position in coincidence with the desired value. This value can either be set manually or by the on-line master computer tia a data transmission system. The optical resolver measures the actual angle on an absolute scale independent of initial conditions. The performance of the resolver itself (precision, accuracy, linearity, thermal drift and long-term stability) determines the performance of the entire positioning system. Therefore it proved to be an excellent calibration reference for other types of goniometer. The availability of absolute position data provides for the automatic insertion of a filter if the goniometer arm enters the region of the primary beam. The thermal drift and mechanical instability of the construction of the goniometer is of little importance to the precision obtained, as the loop immediately corrects any positional error. In addition the loop action interrupts the recording of the intensity detected, while the difference between actual and nominal position exceeds 1 second of arc. The integral action of the controller provides for a high positioning speed while the desired position is approached slowly; there is no restriction of the angular program, allowing the measurement of the primary beam (shape and intensity) as reference for absolute intensity and absolute value of scattering angle repeatedly, while collecting the scattering data. The on-line master computer is able to make calculations and decisions concerning the angular program during the course of the measurement. The combination of the positional loop with an absolute reference and the facilities of the on-line master computer result in the elimination of all practical abscissa error, the elimination of the influence of long-term fluctuations of the primary intensity and a more efficient measuring strategy.
\end{abstract}

